\title{
Analysis of Factors Affecting Income Smoothing Among Listed Companies in Indonesia
}

\author{
Erly Sherlita ${ }^{a^{*}}$, Putri Kurniawan ${ }^{a}$ \\ ${ }^{a}$ Widyatama University Bandung, Indonesia \& Padjadjaran University Bandung, Indonesia \\ *Corresponding author: erly.sherlita@widyatama.ac.id
}

Article history

Received :4 April 2013

Received in revised form : 25 July 2013

Accepted :15 October 2013

\begin{abstract}
This study examines the factors that influence income smoothing practice, such as firm size, profitability, financial leverage, and net profit margin. Grouping among the companies that perform income smoothing, and that does not do income smoothing using Eckel index to net income for the manufacturing companies listed on the Indonesian Stock Exchange. The research sample totaling 68 companies with a sub-sample of 204 financial reports. Observations were made during the three years, from 2008 to 2010. Statistical analysis using binary logistic regression to determine the factors that influence income smoothing. The results showed that the variables of profitability and net profit margins have significant differences between smoothing company profits by not smoothing profits, while the variable firm size and financial leverage has no significant difference. Test results using a multivariate binary logistic regression either simultaneously or separately on the four independent variables thought to affect the practice of income smoothing apparently no one has proved influential. Thus it can be concluded that firm size, profitability, financial leverage, and net profit margin has no effect on the practice of income smoothing.
\end{abstract}

Keywords: Income smoothing; firm size; profitability; leverage

\subsection{INTRODUCTION}

The basic objective of financial statements is to provide useful information for making economic decisions. The accounts also serve as means of accountability of management for the management of company resources. Although all the information contained in the financial statements is very important for the users, based on the fact that there is often only the user's attention focused on the financial statements of earnings information, regardless of how the profit was generated (Beattie et al., 1994).

Most of investors are concerned to earnings information. This condition makes management to take some action dysfunctional behavior, the manipulation of income or earnings management like an income smoothing.

Income smoothing represents managers' attempts to use their reporting discretion to intentionally dampen the fluctuations of their firms'earnings realizations (Beidleman, 1973). It improves earnings informativeness if managers use their discretion to communicate their assessment of future earnings (Tucker and Zarowin, 2005).

The management reduce the fluctuations in reported earnings to match the desired target either artificially through accounting methods, as well as in real terms through transactions (Koch, 1981, Nasir et al., 2002).
Previous studies have been conducted to examine the factors which are allegedly to motivated management to do income smoothing on public companies in Indonesia (Jin and Machfoedz, 1998; Salno and Baridwan, 2000; Murtanto, 2004; Suwito and Herawati, 2005; Juniarti and Corolina, 2005; Zulfa and Maya, 2007; Budiasih, 2009; Kustono, 2009; Aji and Mita,2010).

Jin and Machfoedz (1998) examined factors that may encourage the practice of income smoothing by the company are firm size, type of industry, profitability and operating leverage. The results of this study state that the only factor operating leverage are encouraging the practice of income smoothing. Salno and Baridwan (2000) argues that firm size, net profit margin, business groups and winner/losser stocks have no effect on income smoothing, while Murtanto (2004) explains that the winner / losser stocks affect practice income smoothing .

Suwito and Herawaty (2005), Juniarti and Corolina (2005) and Zulfa and Maya (2007) find that the type of business, firm size, profitability ratio, leverage ratio, market value and net profit margin are none significantly influence income smoothing. Further research carried out by Budiasih (2009) on the factors that influence the practice of income smoothing. The study shows that company size, profitability, dividend payout ratio positively affect income smoothing practices. Meanwhile, financial leverage does not significantly influence the practice of income smoothing. 
Aji and Mita (2010) showed that the numbers of ownership, risk, and firm value are positively influence on the income smoothing.

\subsection{THEORETICAL FRAMEWORK}

The income smoothing hypothesis proposed by Gordon (1964) that emerges as managers' rational behaviour. The assumption of income smoothing are the managers act to maximize their utility, income fluctuation, unpredictable earnings, managers' utility depends on the firm's share value (Beidleman, 1973; Watts and Zimmerman, 1986; and Tucker and Zarowin, 2005).

Eckel (1981) distinguishes two different type of smoothing income stream. Those that are naturally smooth and intentionally smoothed by management. Natural smoothing is the alignments resulting from transactions that inherently produce a smoothed earning. It means, the company's operations to generate income by collecting revenues and expenses are inherently to eliminate fluctuations flow of income. An intentionally smoothed income stream can be the result of real smoothing or artificial smoothing techniques. Real income smoothing indicates management action that seeks to control economic conditions that affect corporate future earnings. Artificial income smoothing occurs when management manipulate the timing of accounting entries to produce smooth income streams.

\subsection{Firm Size and Income Smoothing}

Some previous studies, such as the study conducted by Jin and Machfoedz (1998), Salno and Baridwan (2000), Murtanto (2004), Suwito and Herawaty (2005), Juniarti and Corolina (2005), and Budiasih (2009) measure firm size as one of the factors that may be associated with the practice of income smoothing. Moses (1987) indicated that the big companies are considered to minimize income fluctuation. He found smoothing behavior as subject to management motivation. The big companies are usually required to bear the higher cost because they estimate to have the ability to produce greater profits. Therefore, the company will avoid a drastic increase in profits in order to avoid a charge by the increase of government and society. Albrecht and Richardson (1990) describe the companies that smooth income are small companies. This is because big companies usually receive more attention from investors than analysis and small-sized companies.

\subsection{Profitability and Income Smoothing}

Profitability is measured by the ratio between income after taxes by total assets of the company. Profitability is an important indicator to assess whether or not the company's health that affects investors in decisions making. There are few studies that examine the relationship between corporate profitability with the practice of income smoothing. Ashari et al. (1994) in find evidence that firms with low profitability levels have a greater tendency to practice income smoothing. This is consistent with the research conducted by Aji and Mita (2010), which shows that the higher the level of profitability of the company is. The lower probability of the company will perform income smoothing because companies will increasingly become the public spotlight, so the company is likely trying to take no action that may jeopardize the credibility of the company. However, based on research conducted by Assih et al. (2000), shows that companies with a higher ROA tend to do income smoothing compared with a firm lower because the management knows what would be the ability to earn income in the future to facilitate the delay or accelerate earnings.

\subsection{Financial Leverage and Income Smoothing}

Financial leverage is proxies by debt to total assets obtained through total debt divided by total assets. The company that has low debt ratio is better than high debt ratio. Because, meaning that only a small portion of corporate assets are financed with debt. However, if the debt is used to finance the assets is high; the risk associated with by the owner capital will also be greater. With the assumption that investors and creditors will avoid to invest or lend to companies, so that substantial leverage ratio will cause investors to invest in the company will decrease. Because of such conditions, would lead to management's desire to practice income smoothing in order to attract investors and creditors.

Budiasih (2009) conducted a study to examine the effect of financial leverage on the income smoothing. The results show that financial leverage has no significant effect on the practice of income smoothing. Based on these results, it appears that there are not consistent between the theory and the results of the research.

\subsection{Net Profit Margin and Income Smoothing}

Net profit margin (NPM) is the factors driving the practice of income smoothing. According to Salno and Baridwan (2000), the net profit margin is thought to affect income smoothing, because logical margin is directly related to income smoothing object. Several studies have been conducted to examine the effect on the net profit margin income smoothing.

Suwito and Herawaty (2005), and Zulfa and Maya (2007) study show that the net profit margin has no effect on income smoothing. Based on these results, it appears that there is still disagreement about the effect of net profit margin on the practice of income smoothing. Logically, this can be said margins affect income smoothing as directly related to income smoothing object, but instead results indicate that there is no effect. The variable net profit margin is still worth to be reexamined related effects on income smoothing practices.

\subsection{METHODOLOGY}

This research is employed the coefficient of variation method developed by Eckel (1981) to determine the presence of income smoothing. In this method, the coefficient of variations is used to measure the variability of sales and income.

Income smoothing index is calculated as follows: Income Smoothing Index $=\underline{\mathrm{CV} \Delta \mathrm{I}}$

$\Delta \mathrm{I}$ : Income change $\mathrm{CV} \Delta \mathrm{S}$

$\Delta \mathrm{S}$ : Sales change

$\mathrm{CV}$ :Coefficient variations

$\mathrm{CV} \Delta \mathrm{I}<\mathrm{CV} \Delta \mathrm{S}$, income smoother group $\mathrm{CV} \Delta \mathrm{I}>\mathrm{CV} \Delta \mathrm{S}$, non income smoothers group

CV $\Delta \mathrm{I}$ : coefficient of variation for the change in income $\mathrm{CV} \Delta \mathrm{S}$ : coefficient of variation for the change in sales 


\subsection{Sample Selection}

This research using purposive judgment sampling method. The observation period in this study was for 3 years from 2008 to 2010. The criteria of sample selection are; manufacturing companies were listed in the Indonesian Stock Exchange from 2006-2010, companies did not make acquisitions or mergers during the period of observation, and did not get losses from 2006 to 2010.

\subsection{Univariate Testing}

Three diagnostic procedures were used to test the normality underlying the logistic regression model. First, we tested OneSample Kolmogorov-Smirnov Test for normality existence. This procedure identified the normality distribution result, it can be seen what type of test to be used for further testing. Second,if the variable is normally distributed, it will be used independent sample t-test. Third, if the variable is not normal distributed, use Mann-Whitney Test will be used. Independent sample t-test is done to test the normal distribution of data. In this case, a normally distributed variable is financial leverage. $T$ test aims to see whether there are differences between the company's financial leverage and corporate profits instead income smoothing. Mann-Whitney test aims to see differences in the variables tested between the companies. This test was used to test the data were not normally distributed, in this case the company size, profitability, and the company's net profit margin between smoothing and non-smoothing.

\subsection{Multivariate Testing}

This study uses logistic regression, the dependent variable is used as a dummy variable in which the variables are categorized under code 0 and 1 . In this study, the dependent variable was coded 0 if the company does not perform income smoothing, whereas the dependent variable was coded 1 if the company made a practice of income smoothing.

Overall fit model were used to test whether a logistic regression model equation obtained suitable or appropriate for use in predicting income smoothing (1) and not smoothing return (0). The test is performed by comparing the values between $-2 \log$ likelihood at baseline (block number $=0$ ) with a value of $-2 \log$ likelihood at the end (block number =1). A reduction in the value between $-2 \log$ likelihood initial $-2 \log$ likelihood value in the next step (-2log likelihood end) shows that the hypothesized model fit the data and -2 Log likelihood values at baseline (block number $=0$ ). At the end of the Test, the feasibility test of a logistic regression model done using goodness of fit test as measured by the value of chi square.

Based on the review of the literature, the model we test is of the following general form:

$\mathrm{TP}=\mathrm{a}+\mathrm{b}(\mathrm{UP})+\mathrm{c}(\mathrm{PP})+\mathrm{d}(\mathrm{FLP})+\mathrm{e}(\mathrm{NPM})$

Where:

TP : Income smoothing practice

UP : Firm size (Ln Total Asset)

PP : Profitability (Earnings After Tax/Total Asset)

FLP : Financial leverage (Debt to Total Asset)

NPM : Net profit margin

a : constant coefficients

b : firm size coefficients

c : profitability coefficient

d : financial leverage coefficient

e : net profit margin coefficient

\subsection{FINDING AND DISCUSSION}

Based on the criteria of sample selection, we obtained 68 $(45,63 \%)$ companies from 149 companies. The amounts of the observation year were 204 financial statements.

During the observation period of the years 2008-2010, in calculating the index from the years 2008-2010 Eckel required data from the years 2006-2010 to calculate the Eckels' Index each year. Furthermore the entire sample further classified into income smoothers $(0)$ and non income smoothers (1). Based on the analysis of the 204 financial statements, there were 123 fiancial statements $(60.3 \%)$, which indicate income smoothers and 81 financial statements $(39.7 \%)$ were non income smoothers companies.

Test for normality using Kolmogorov Smirnov One Sample Test done first to test the normality of the data from each independent variables.

Table 1 One sample Kolmogorov-Smirnov test

\begin{tabular}{lc}
\hline \multicolumn{1}{c}{ Variable } & Asymp. Sig (2-tailed) \\
\hline Size & 0,000 \\
Profitability & 0,000 \\
Financial Leverage & 0,404 \\
Net Profit Margin & 0,000 \\
\hline
\end{tabular}

The table above shows that only financial leverage variable has a probability value or Asymp. Sig (2 - tailed) more than $0.05(0.404>0.05)$, that means the variable is normally distributed. The other variables such as firm size, profitability, and net profit margin has a probability value or Asymp. Sig (2tailed) less than 0.05 and not normally distributed, so the univariate tests for these variables using Mann-Whitney test. Thus, the univariate tests for financial leverage using independent sample t-test because the variable is normally distributed.

Table 2 Independent sample t-test

\begin{tabular}{rcc}
\hline & $\begin{array}{c}\text { Levene's Test for Equality } \\
\text { of Variances } \\
\text { F }\end{array}$ & Sig. \\
\hline $\begin{array}{r}\text { FLP Equal } \\
\text { variances } \\
\text { assumed }\end{array}$ & 3.256 & .073 \\
\hline
\end{tabular}

\begin{tabular}{|c|c|c|c|c|c|c|}
\hline \multicolumn{7}{|c|}{ t-test for Equality of Means } \\
\hline \multirow[t]{2}{*}{$\mathrm{t}$} & \multirow[t]{2}{*}{$\mathrm{df}$} & \multirow[t]{2}{*}{\begin{tabular}{|l|} 
Sig \\
$(2-$ \\
tailed $)$
\end{tabular}} & \multirow[t]{2}{*}{$\begin{array}{c}\text { Mean } \\
\text { Differenc } \\
\mathrm{e}\end{array}$} & \multirow[t]{2}{*}{$\begin{array}{l}\text { Std. Error } \\
\text { Difference }\end{array}$} & \multicolumn{2}{|c|}{$\begin{array}{l}95 \% \text { Confidence } \\
\text { Interval of the } \\
\text { Difference }\end{array}$} \\
\hline & & & & & Lower & Upper \\
\hline 1.44 & 202 & .150 & $\begin{array}{c}.038262 \\
2\end{array}$ & $\begin{array}{c}.026502 \\
2\end{array}$ & -.01399 & .09052 \\
\hline 1.41 & 160 & .158 & $\begin{array}{c}.038262 \\
2\end{array}$ & $\begin{array}{c}.027000 \\
2\end{array}$ & $\begin{array}{c}- \\
.015059\end{array}$ & .09158 \\
\hline
\end{tabular}

The table above shows that the Levene test $F$ count of 3.256 with a probability of 0.073 . Because the probability of greater than $0.05(0.073>0.05)$, it can be concluded that hypothesis did not reject or have the same variance. Thus, the 
analysis of different test t-test assuming equal variance must use assumed.

From the table above, it can be seen that the company's financial leverage statistical significance value greater than 0.05 (0.150), which means the company financial leverage is not significant at the 0.05 level. The results of these tests resulted that Ho is rejected, which means that there is no difference in the average financial leverage company doing income smoothing and companies that do not perform income smoothing. It is also evident from the difference in the average financial leverage variables are very small, amounting to 0.0382622 (mean smoothing company profits mean 0.476463 and 0.438201 profit company instead grader).

Mann-Whitney test was used to test the data were not normally distributed, in this case the company size, profitability, and the company's net profit margin between smoothing and non-smoothing. The test results obtained are as follows:

Table 3 Mann-Whitney Test

\begin{tabular}{l|c|c|c}
\hline & Firm Size & Profitability & $\begin{array}{c}\text { Net Profit } \\
\text { Margin }\end{array}$ \\
\hline $\begin{array}{l}\text { Mann- } \\
\text { Whitney U }\end{array}$ & 4.669 .000 & 4.009 .000 & 4.011 .000 \\
$\begin{array}{l}\text { Wilcoxon } \\
\text { W }\end{array}$ & 12.295 .000 & 11.635 .000 & 11.637 .000 \\
Z & -.776 & -2.357 & -2.352 \\
$\begin{array}{l}\text { Asymp. Sig. } \\
\text { (2-tailed) }\end{array}$ & .438 & .018 & .019 \\
\hline
\end{tabular}

From the table above it can be seen that the probability of firm size variable is greater than $0.05(0.438>0.05)$. The results of these tests resulted that Ho is rejected, which means that there is no significant difference for the variable firm size between smoothing and non-smoothing. We also see that the mean rank smoothing company profits are smaller than firms not smoothing earnings $(99.96<106.36)$. So it can be concluded that the company had a profit of firm size smoothers that are smaller than firm size non income smoothers.

Profitability variable has a probability value of less than $0.05(0.018<0.05)$. The results of these tests resulted Ho is rejected, which means that there are significant differences for the variables profitability between company's grader profit and not profit. We also see that the mean rank smoothing company are smaller than non-smoothing earnings $(94.59<114.51)$. So it can be concluded that the company had a profit graders lower profitability of the company is non income smoothers.

Net profit margin variable has a value less than the probability $0.05(0.019<0.05)$. The results of these tests resulted Ho is rejected, which means that there are significant differences for the variable net profit margin between smoothing and non-smoothing. We also see that the mean rank grading company profits are smaller than firms not grading earnings (94.61<114.48).
Table 4 Logistic regression model

\begin{tabular}{|c|c|c|c|c|c|c|}
\hline & B & S.E. & $\begin{array}{c}\text { Wal } \\
\text { d }\end{array}$ & df & Sig. & $\operatorname{Exp}(B)$ \\
\hline Step $1^{\mathrm{a}} \quad$ Size & -.037 & .101 & 138 & 1 & .711 & .963 \\
\hline & -2.860 & 2.378 & 1.44 & 1 & .229 & .057 \\
\hline Profitability & .656 & .901 & $\begin{array}{r}7 \\
.531\end{array}$ & 1 & .466 & 1.928 \\
\hline $\begin{array}{l}\text { Financial } \\
\text { Leverage }\end{array}$ & & & & & & \\
\hline $\begin{array}{l}\text { Net Profit } \\
\text { Margin }\end{array}$ & -.135 & 2.718 & .002 & 1 & .960 & .874 \\
\hline Constant & 1.451 & 2.717 & .285 & 1 & .593 & 4.266 \\
\hline
\end{tabular}

From the table above between the independent variablesand the dependent variable as follows:

\section{$I S=1,451-0,037$ UP $-2,860$ PP + 0,656 FLP $-0,135$ NPM}

Constants of 1.451 states that if the value does not account for firm size, profitability, financial leverage, and net profit margin, then it is likely that the company practice of income smoothing is 1.451.The test showed that the firm size has a value of probability is 0,711 and on the parsial stage, a value of probability is 0.705 . Both of value is even greater than level of significance 0.1 , so that firm size does not have affect income smoothing practices.

After obtained equation logistic regression models, we test model fit, the feasibility of regression models and testing individually independent variables to test whether the variables included in the model significantly influence income smoothing.

\subsection{Overall Fit Model}

Testing is done by comparing the values between -2 Log Likelihood $(-2 L L)$ early (Block Number $=0$ ) with end-2LL (Block Number $=1)$. A reduction in-2LL between the initial value (initial-2LL function) with a value of-2LL in the next step ( $-2 \mathrm{LL}$ end) shows that the hypothesized model fit the data. It can be demonstrated by the following table:

Table 5 -2 Log Likehood (-2LogL begin) Block 0: Beginning Block

\begin{tabular}{|c|c|c|}
\hline \multicolumn{3}{|c|}{ Iteration History $\mathbf{a}, \mathbf{b}, \mathbf{c}$} \\
\hline Iteration & $-2 \log$ & Coefficients \\
\hline & likelihood & Constant \\
\hline $\begin{array}{ll}\text { Step 0 } & 1\end{array}$ & 274.097 & .412 \\
\hline 2 & 274.095 & .418 \\
\hline 3 & 274.095 & .418 \\
\hline
\end{tabular}

Table 6 -2 Log Likehood (-2LogL end)

Block 1: Method = Enter Iteration History $\mathbf{a}, \mathbf{b}, \mathbf{c}$

\begin{tabular}{cllllll}
\hline Iteration & $\begin{array}{l}-2 \\
\text { likelihood Constant }\end{array}$ & $\mathbf{X 1}$ & $\mathbf{X 2}$ & $\mathbf{X 3}$ & $\mathbf{X 4}$ \\
& & & & & & \\
\hline $\begin{array}{c}\text { Step1 } \\
1\end{array}$ & 267.725 & 1.630 & -.048 & -2.017 & .745 & -.131 \\
2 & & & & & & \\
& & 1.484 & -.039 & -2.746 & .676 & -.135 \\
3 & & & & & & \\
4 & & 1.451 & -.037 & -2.585 & .657 & -.135 \\
5 & & 1.451 & -.037 & -2.860 & .656 & -.135 \\
& & 1.451 & -.037 & -2.860 & .656 & -.135 \\
\hline
\end{tabular}


The first step shows that the value of $-2 \log$ likelihood with block number $=1$, and the value of $-2 \log$ likelihood in the second step is changing after the entry of several independent variables in the research model, as a result the value of $-2 \log$ likelihood (-2LogL end) in step 5 showed a value of 267.479. In addition, there is a reduction in the value of the log likelihood -2 $-2 \log$ likelihood beginning with the end, in the amount of 6.616 which can be seen in Table 4. This suggests that the hypothesized model fit the data.

Decline in the value of $-2 \log$ likelihood in the table 6 shows that this research model otherwise fit, meaning the additions of independent variables; firm size, profitability, financial leverage, and net profit margin in the research model to improve the model fit.

Table 7 Omnibus tests of model coefficient

\begin{tabular}{llccc}
\hline & & Chi-square & Df & Sig. \\
\hline Step1 & Step & 6.616 & 4 & .158 \\
& Block & 6.616 & 4 & .158 \\
& Model & 6.616 & 4 & .158 \\
\hline
\end{tabular}

\subsection{Goodness of Fit Tests}

The feasibility testing of a logistic regression model is done using Hosmer and Lemeshow's Goodness of Fit Test as measured by the Chi-Square.

Table 8 Hosmer and Lemeshow test

\begin{tabular}{cccc}
\hline Step & Chi-square & df & Sig. \\
\hline 1 & 5.500 & 8 & .703 \\
\hline
\end{tabular}

Table above shows that the value of Hosmer and Lemeshow test was 5.500. A significance probability is 0.703 . Significance probability value of 0.703 is much greater than the significance level of 0.05 . It can be concluded that the regression model is acceptable.

Furthermore, for more convincing results of simultaneous multivariate testing measured by backward stepwise to estimate the parameters for the full model which includes the final model from previous method and all eligible variables.

Table 9 Model summary

\begin{tabular}{llcc}
\hline Step & $\begin{array}{l}\mathbf{- 2} \\
\text { likelihood }\end{array}$ & $\begin{array}{c}\text { Cox \& Snell } \\
\text { RSquare }\end{array}$ & $\begin{array}{c}\text { Nagelkerke } \\
\text { RSquare }\end{array}$ \\
\hline 1 & $267.481^{\mathrm{a}}$ & .032 & .043 \\
2 & $267.625^{\mathrm{a}}$ & .031 & .042 \\
3 & $268.126^{\mathrm{a}}$ & .029 & .039 \\
\hline
\end{tabular}

Table 10 show the variables firm size, profitability, and financial leverage from are eligible for entry and removal. The current model show that profitability affect income smoothing practice and Nagelkerke R Square means showed that the effect of profitability on income smoothing is $4.3 \%$ and $95.7 \%$ of income smoothing practices are influenced by other variables.

Based on the current model, fim size variable is the largest significance and removal for next step. After modifying current model by removing firm size, we estimate the parameters for the modified model and go back to step 2 . Second step show that the effect of profitability on income smoothing is $4,2 \%$ and the final step show that effect of profitability on income smoothing is $3,9 \%$

Table 10 Logistic regression model variables in equation

\begin{tabular}{|c|c|c|c|c|c|c|}
\hline \multirow{2}{*}{\multicolumn{7}{|c|}{$\overline{\text { Step } 1^{\mathrm{a}}}$}} \\
\hline & -038 & 100 & 143 & 1 & & \\
\hline Size & $\begin{array}{l}. .038 \\
-2.936\end{array}$ & 1.816 & $\begin{array}{c}.143 \\
2.615\end{array}$ & $\begin{array}{l}1 \\
1\end{array}$ & .106 & $\begin{array}{l}.903 \\
.053\end{array}$ \\
\hline $\begin{array}{l}\text { Profitability } \\
\text { Financial }\end{array}$ & .670 & .858 & .609 & 1 & .435 & 1.954 \\
\hline $\begin{array}{l}\text { Leverage } \\
\text { Constant }\end{array}$ & 1.457 & 2.714 & .288 & 1 & .591 & 4.292 \\
\hline $\begin{array}{l}\text { Step } 2^{\mathrm{a}} \\
\quad \text { Profitability }\end{array}$ & $\begin{array}{r}-3.132 \\
.592\end{array}$ & $\begin{array}{l}1.777 \\
.835\end{array}$ & $\begin{array}{l}3.106 \\
.503\end{array}$ & $\begin{array}{l}1 \\
1\end{array}$ & $\begin{array}{l}.078 \\
.478\end{array}$ & $\begin{array}{l}.044 \\
1.808\end{array}$ \\
\hline $\begin{array}{l}\text { Leverage } \\
\text { Constant }\end{array}$ & .446 & .486 & .845 & 1 & .358 & 1.563 \\
\hline $\begin{array}{l}\text { Step } 3^{\mathrm{a}} \\
\text { Profitability } \\
\text { Constant }\end{array}$ & $\begin{array}{r}-3.587 \\
.758\end{array}$ & $\begin{array}{l}1.714 \\
.215\end{array}$ & $\begin{array}{c}4.379 \\
12.433\end{array}$ & $\begin{array}{l}1 \\
1\end{array}$ & $\begin{array}{l}.065 \\
.000\end{array}$ & $\begin{array}{c}.028 \\
2.135\end{array}$ \\
\hline
\end{tabular}

\subsection{Firm Size}

The result of this study is consistent with the Jin and Machfoedz (1998), Salno and Baridwan (2000), Murtanto (2004), Suwito and Herawaty (2005), Juniarti and Corolina (2005) but contrary with Budiasih (2009). Budiasih (2009) find that the firm size has a positive influence on income smoothing practices.

Firm size, is believed can be used as a parameter in analyzing its influence against income smoothing (Salno and Baridwan, 2000). It turns out does not proven with the results obtained from this research. It means that total assets is less precise for used as a benchmark magnitude of a enterprise. With Thus made possible the existence of other components which can be used stock price as parameter in measuring the magnitude of company of its prosperity that reflected in the stock market value (Grant, 2005).

\subsection{Profitability}

Multivariate test show that the profitability has no effect on the income smoothing on 0.1 significance level, but in parsial multivariate testing showed that the profitability affect income smoothing. Profitability variable has a probability value of 0.229 in simultaneously multivariate testing, 0.106 backward stepwise step II, 0.078 in step III, and the 0.065 in step IV. The test of the profitability variable obtained empirical evidence that profitability has a statistically significant impact on income smoothing practices.

From the results of the testing of hypotheses, univariate test show that there are significant differences between the company's profitability of income smoothers and non income smoothers. We also see that the mean rank grading company profits are smaller than company earnings instead of grading (94.59 <114.51). It can be concluded that the income smoothers companies have lower profitability than non income smoothers companies. This finding is consistent with Budiasih (2009) who found that profitability has an influence on the practice of income smoothingbut contrary with Jin and Machfoedz (1998), Suwito and Herawaty (2005), Juniarti and Corolina (2005), Aji and Mita (2010). 


\subsection{Financial Leverage}

Results of multivariate testing both simultaneously and separately show that the independent variables in financial leverage has no effect on the income smoothing on significance 0.1 , because financial leverage has a probability value of 0.466 in simultaneously multivariate testing, probability value of 0.435 in step II, and 0.478 in step III. This finding is consistent with Budiasih (2009). Financial leverage on income smoothing presumably because there is the convenience provided capital markets in facilitating the company's debt payments so that the risk posed by the debt can be reduced.

\subsection{Net Profit Margin}

Results of multivariate testing both simultaneously and separately show that probability value of net profit margin indicates greater than the significance level of 0.1 (0.960). It means the net profit margin does not have an impact on income smoothing practices.

Net profit margin is expected to affect the practice of income smoothing because logically this margin is directly related to income smoothing object. However, the results of this study failed to prove the existence of the effect on the net profit margin income smoothing. The finding is consistent with Salno and Baridwan (2000), Murtanto (2004), Suwito and Herawaty (2005), and Zulfa and Maya (2007). Low profit margin indicates that company has high rate of return.

\subsection{CONCLUSION}

Using the Eckels' Index, we find that profitability and net profit margins significant differences between smoothing firm and non-smoothing firm, while the variable firm size and financial leverage has no significant difference between smoothing firm and non-smoothing firm. Our paper present the empirical evidence that profitability affect the firm to smooth their reported income.

Our statistical model and measured variables are subject to a number of limitations that could affect the results. First, we use Eckels' Index due to the limited sample. Second, some of the proxies for the theoretically guided factors such as firm size and financial leverage could be incomplete. Third, time period of the observation is too short when compared to other studies which may include a period of time until more than ten year, and there are many other factors that may have a significant influence but cannot detected.

Finally, it may be necessary, following Michelson Index (1995), Albrecht and Richardson (1990) measure, or Tucker and Zarowin (2006) income smoothing measure for more effectively match the objectives of income smoothing studies (Faello, 2012). Further study will address gathering better and more extensive data, extend time period, determinant, and factors to incorporate the variables that affect income smoothing practice where possible.

\section{References}

[1] Aji, Dhamar Yudo dan Mita, Aria Farah. 2010. Pengaruh Profitabilitas, Risiko Keuangan, Nilai Perusahaan, dan Struktur Kepemilikan Terhadap Praktek Parataan Laba: Studi Empiris Perusahaan Manufaktur yang Terdaftar di BEI. Simposium Nasional Akuntansi XIII. Purwokerto.

[2] Albrecht, W. David and Frederick M. Richardson. 1990. Income Smoothing by Economy Sector. Journal of Business Finance and
Accounting. 17(5).

[3] Assih, Prihat dan M. Gudono. 2000. Hubungan Tindakan Perataan Laba dengan Reaksi Pasar atas Pengumuman Informasi Laba Perusahaan yang Terdaftar di Bursa Efek Jakarta. Jurnal Riset Akuntansi Indonesia. 3(1): 35-53.

[4] Beattie, Vivien, Broen Steophen, Ewers David, John Brian, Manson Stuart, Thomas Dylan, and Turner Michael. 1994. Extraordinary Items and Income Smoothing: A Positive Accounting Approach, Journal of Business Finance and Accounting. September, 791-811.

[5] Budiasih, I. G. A. N. 2009. Faktor-Faktor yang Mempengaruhi raktik Perataan Laba. AUDI Jurnal Akuntansi dan Bisnis. 4(1): 4450.

[6] Eckel, Norm. 1981. The Income Smoothing Hypothesis Revisited. Abacu. 17(1): 28-40.

[7] Jensen, Michael C. and William H. Meckling. 1976. Theory of The Firm: Managerial Behaviour, Agency Cost and Ownership Structure. Journal of Financial Economics. 3(4): 305-306.

[8] Jin, Liauw She dan Mas'ud Machfoedz. 1998. Faktor-Faktor yang memperngaruhi Praktik Perataan Laba pada Perusahaan yang Terdaftar di Bursa Efek Jakarta. Jurnal Riset Akuntansi Indonesia. 1(2): 174-191.

[9] Juniarti dan Corolina. 2005. Analisa Faktor-faktor yang Berpengaruh terhadap Perataan Laba Pada Perusahaan-perusahaan Go Public Manufaktur yang Terdaftar di Bursa Efek Jakarta. Jurnal Akuntansi dan Keuangan. 7(2): 148-162.

[10] Koch, Bruce, S. 1981. Income Smoothing An Experiment. The AccountingReview. LVI (3): 574-586.

[11] Kustono, Alwan Sri. 2011. The Theoretical Contruction of Income Smoothing Measurement. Journal of Economics, Business and Accountancy Ventura. 14(1): 59-78.

[12] Michelson, S., J. J. Wagner, and C. W. Wooton. 1995. A Market Based Analysis of Income Smoothing. Journal of Business Finance and Accounting. 228: 0306-686x.

[13] Moses, O. D. 1987. Income Smoothing and Incentives:Empirical Test Using Accounting Changes. The Accounting Review. 62(2): 358-377.

[14] Mursalim. 2005. Income Smoothing dan Motivasi Investor: Studi empiris pada Investor di BEJ. Simposium Nasional Akuntansi VIII. Solo.

[15] Murtanto. 2004. Analisis Perataan Laba (Income Smoothing): Faktor-faktor yang Mempengaruhi dan Kaitannya dengan Kinerja Saham Perusahaan Publik di Indonesia. Simposium Nasional Akuntansi VII. Bali.

[16] Nasir, Arifin dan Anna Suzanti. 2002. Analisis Pengaruh Perataan Laba Terhadap Risiko Pasar Saham dan Return Saham Perusahaan-perusahaan Publik di Bursa Efek Jakarta. KOMPAK. Mei.

[17] Rahmawati. 2006. Pengaruh Asimetri Informasi Terhadap Praktik Manajemen Laba pada Perusahaan Perbankan Publik yang Terdaftar di BEJ. Simposium Nasional Akuntansi IX. Padang.

[18] Salno, Hanna Meilani dan Baridwan, Zaki. 2000. Analisis Perataan Penghasilan (Income Smoothing): Faktor-faktor yang Mempengaruhi dan Kaitannya dengan Kinerja Saham Perusahaan Publik di Indonesia. Jurnal Riset Akuntansi Indonesia. 3(1): 17-34.

[19] Sandra, Dessy dan Indra Wijaya Kusuma. 2004. Reaksi Pasar Terhadap Tindakan Perataan Laba dengan Kualitas Auditor dan Kepemilikan Manajerial sebagai Variabel Pemoderasi. Simposium Nasional Akuntansi VII. Bali.

[20] Scott, William R. 2003. Financial Accounting Theory. Third Edition. USA: Prentice-Hall.

[21] Setiawati, Lilis dan Na'im, Ainun. 2000. Manajemen Laba. Jurnal Ekonomi dan Bisnis Indonesia. 15(4): 424-441.

[22] Subekti, Imam. 2005. Asosiasi antara Praktik Perataan Laba dan Reaksi Pasar Modal di Indonesia. Simposium Nasional Akuntansi VIII. Solo.

[23] Sutrisno. 2002. Studi Manajemen Laba (Earnings Management): Evaluasi Pandangan Profesi Akuntansi, Pembentukan dan Motivasinya. Kompak. 5: 158-179.

[24] Suwardjono. 2006. Teori Akuntansi: Perekayasaan Laporan Keuangan. Edisi Ketiga, Yogyakarta: BPFE.

[25] Suwito, Edy dan Herawaty, Arleen. 2005. Analisis Pengaruh Karakteristik Perusahaan Terhadap Tindakan Perataan Laba yang Dilakukan oleh Perusahaan yang Terdaftar di Bursa Efek Jakarta. Simposium Nasional Akuntansi VIII. Solo.

[26] Tucker, Jennifer W. and Paul A. Zarowin. 2006. Does Income Smoothing Improve Earnings Informativeness? The Accounting Review. 81(1): 251-270

[27] Watts, R, L., and Zimmerman, J, L. 1986. Positive Accounting Theory. New York: Prentice Hall.

[28] Yusuf, Muhammad dan Soraya. 2004. Faktor-faktor yang Mempengaruhi Praktik Perataan Laba Pada Perusahaan Asing dan 
Non Asing di Indonesia. Jurnal Akuntansi dan Auditing Indonesia, 8: 1.

[29] Zulfa dan Maya. 2007. Analisis Perataan Laba: Faktor yang Mempengaruhinya dan Pengaruhnya Terhadap Return dan Risiko
Saham Perusahaan Go Public di Bursa Efek Jakarta. BENEFIT. 11(1): 46-50. 